\title{
食品廃棄物の凍結・解凍・脱水処理のための凍結脱水機の試作
}

\author{
四宮陽子 ${ }^{1, \dagger}$, 宮脇長人 ${ }^{2}$ \\ ${ }^{1}$ 実践女子大学生活科学部食生活科学科, ${ }^{2}$ 石川県立大学生物資源環境学部食品科学科
}

\section{A Test Apparatus for Freezing-thawing Dehydration of Food Wastes}

\author{
Yoko SHIMIYA $^{1, \dagger}$ and Osato MIYAWAKI ${ }^{2}$ \\ ${ }^{1}$ Department of Food and Health Sciences, Jissen Women's University, 4-1-1, Osakaue, Hino-shi, Tokyo 191-8510, Japan \\ ${ }^{2}$ Department of Food Science, Ishikawa Prefectural University, 1-308, Suimatsu, Nonoichi, Ishikawa 921-8836, Japan
}

\begin{abstract}
Freezing-thawing-dehydration technique is expected as a safe and energy-saving method for the treatment of food waste. A test apparatus was made by combining an electric cleaning machine with centrifuge and a refrigerator for the treatment of food waste in several kilogram scale. Food waste was frozen at $-20{ }^{\circ} \mathrm{C}$, thawed at room temperature, and centrifuged at $142 \mathrm{xg}$. Twenty-five food waste samples, including vegetables and fruits with skins and cores, and gel materials, were treated by this apparatus. As a result, the average water content decreased from $88.38 \%$ to $74.57 \%$ to reduce the residual weight fraction down to $46.62 \%$. In addition, food wastes and leftovers of 130 meals for 3 days in "Practice of Feeding Management II" a practical exercise in J women's university, were effectively dehydrated to reduce their average weight to $53 \%$ except 1 leftover. Freezing-thawing-dehydration treatment prevents decomposition of food waste free from offensive odor. Thus this method is expected to be applicable widely for recycle, transportation, and incineration of food wastes.
\end{abstract}

Keywords: freezing-thawing-dehydration, freezing-dehydrating machine, food waste reduction, food waste dehydration, composting of food waste

\section{1. 緒}

平成 13 年 5 月に「食品リサイクル法」（食品資源の 再生利用等の促進に関する法律）が施行され [i]，年間 100 トン以上の食品廃棄物を排出する事業者に対して 5 年間で $20 \%$ の排出減を義務付けた。その結果，平成 15 年度は食品産業（食品製造業, 食品卸売業, 食品小売業, 外食産業）計の再生利用等の実施率が $45 \%$ [ii] と，まず まずの数值が挙げられている。しかし食品製造業の廃 棄物は産業廃棄物として扱われていたため, 平成 8 年 の厚生省（当時）資料に基づく農林水産省の推計です でに焼却以外の再利用率が $48 \%$ であり [i]，平成 15 年 度には $71 \%$ に達していたので [ii]，これを除いた食品産 業の再生利用等の実施率計は, $30 \%$ と下がってくる [ii]. また, 食品廃棄物発生の内訳は [i], 産業廃棄物（食品 製造業） 340 万トン／年，一般廃棄物事業系 600 万トン

(受付 2005 年 6 月 29 日，受理 2005 年 11 月 28 日)

1 ₹ 191-8510 東京都日野市大坂上 4-1-1

2 个 921-8836 石川県石川郡野々市町末松 1-308

† Fax: 042-585-8818, E-mail: yshimiya@univ.jissen.ac.jp
／年，一般廃棄物家庭系 1000 万トン／年と家庭系が最 も多いが，家庭系は「食品リサイクル法」の対象外で あり，有効な手段は取られていないので全体の食品廃 棄物減量には疑問が残る。今後さらに排出現場での減 量・減容化の必要性が高まるが [1]，そのためには家庭 などにおける原点処理に利用できる小規模でも使用可 能で安全かつ省エネルギ的な方法の開発が望まれる.

現在, 生ごみ減量を目的として市販されている生ご み処理機にはバイオ方式（微生物による分解方式）と 乾燥方式がある [iii]．これらは発生した生ごみをなる ベく簡単に安価に0にする，という発想で作られてお り，発想の根本は焼却処分と同質である。しかし食品 廃棄物（生ごみ）は有機物であり，飼料，肥料，メ夕 ンガス，油脂などの資源として利用可能な物質である ので，0にするのではなく有効に利用することを考慮し た処理が必要と考えられる。

食品廃棄物は水分が多いので，重量が重いだけでな く腐敗変質やにおいが問題になる。したがって，発生 直後の小規模の段階で，ある程度脱水できると次の処 理がスムースになる．前報では家庭など小規模でも使 用可能な方法として，凍結・解凍を利用した食品廃棄 
物の脱水処理を提案した [2].この方法は食品廃棄物を 凍結することにより，水結晶生成による細胞構造破壊， 凍結変性, 凍結濃縮, 水和構造の変化などが生じ, 解 凍後に脱水されやすくなることを利用した方法である. 食品の凍結・解凍による物性や細胞構造変化について は，複素インピーダンスとレオロジ測定による報告が ある [3-5]. さらに凍結・解凍・脱水法は乾燥と比較し て省エネルギ的であり，凍結により腐敗やにおい発生 を防止できる利点もある．前報では荷重圧搾機と遠心 分離機を用いて $20 \mathrm{~g}$ 程度の小規模実験を行ったが，測 定した約 40 種の食品および調理くずに対して処理前の 平均水分含量 $86.0 \%$ から処理後平均水分含量 $76.9 \%$, 平 均残さ重量比 $54.5 \%$ の結果が得られた。そこで本実験 では凍結・解凍・脱水法の実用化に向けて, 数 $\mathrm{kg}$ 程度 の食品廃棄物処理が可能な凍結脱水機を試作して，実 際の給食提供の場における食品廃棄物処理を行い，そ の効果について検討した.

\section{2. 実験}

\section{1 試料}

野菜や果物は市販品を用い，水分含量 $90 \%$ 以上の野 菜 11 種，水分含量 $90 \%$ 以下の野菜 5 種，果物 6 種を選 択した。 ゲル状食品は, コンニャク (有)古沢食品), 卜 ウフ (株むむつ)，カマボコ（侏)友月）を使用した。

実際の給食提供における食品廃棄物試料として，J 女 子大学食生活科学科管理栄養士専攻の 4 年生授業「給 食管理実習 II (130 食) における調理に伴う食品廃棄 物と供食後の食べ残しを回収した。

\section{2 凍結脱水機}

1 度に数 $\mathrm{kg}$ 程度の食品廃棄物を凍結・解凍 ·脱水処 理できる装置として，一槽式遠心脱水機付洗濯機 (ASW-A60VP (W), 三洋電機(株)) に $-40^{\circ} \mathrm{C}$ の冷凍機モ一 夕（UF-NRH410 SF，三洋電機(侏)，400 W) を連結して 冷媒を循環させ脱水機を断熱材で覆い，脱水機内で試 料を凍結できる凍結脱水機を試作した．凍結脱水機の 回転数は $142 \mathrm{xg}(760 \mathrm{rpm})$ であった.

\section{3 温度測定方法}

凍結脱水機で試料を凍結・解凍させた時の温度測定 は，凍結脱水機内と室内温度はボタン型クールメモリ (SEC-CD16TB 三洋電機(侏)）で測定し，パソコン用ボ タン型クールメモリリーダ（SEC-CD135RW 三洋電 機(株)）で解析した。食品試料内部温度は熱電対 (THERMO PRINTER AP-210 安立計器(株)) にニード ルタイプセンサ (513E 安立計器(株)) を取り付けて測 定した。

\section{4 凍結・解凍・脱水操作}

実際の食品廃棄物処理を想定して，食品試料は 1 回 に500 g 以上を使用し，可食部と非可食部を分けずに 用いた。試料の重量を測定し，重量バランスを取るた め 4 つ以上に等分したものを，それぞれビニル袋（ポ リエチレン製。(株)紙叶）中にメッシュ袋（ポリエチレン 製. 日本技研株式会社)を入れた凍結脱水用の袋に入れ, 凍結脱水機で 24 時間以上かけて完全に凍結させた. 解 凍は凍結脱水機の電源を切り蓋を開けてそのまま放置 した. 試料が完全に解凍した後凍結脱水袋のメッシュ 袋を持ち上げ残さとドリップに分離し，残さの入った メッシュ袋を凍結脱水機内に均等に置き，所定の時間 遠心脱水して，脱水後の残さ重量を測定した.

「給食管理実習 II」で回収した食品廃棄物試料は，重 量バランスを取るために $250 \mathrm{~g}$ ずつ分けて凍結脱水袋 に入れ，密閉して凍結脱水機で 24 時間以上凍結させた. その後は前述の食品試料と同様に解凍 ·脱水操作を行 い, 残さ重量を測定した。

\section{5 脱水効果の評価}

食品試料の脱水効果は, 凍結前と凍結 ·解凍 ·脱水 後の水分含量の比較と, 凍結 - 解凍 - 脱水後の残さ重 量比から評価した. 凍結前の食品試料水分含量は $105^{\circ} \mathrm{C}$ 常圧乾燥法で測定したが，果物は糖が多量に存在する ため $135^{\circ} \mathrm{C}$ 常圧乾燥法で 2 時間乾燥した。また凍結・解 凍·脱水後の水分含量は, 皮や芯などをつけたまま脱 水したため部位差が大きくなったので，下に示した式 から求めた.

$$
W_{f}=\left(W_{i}+R-100\right) / R \times 100
$$

ただし， $W_{f}$ は脱水後水分含量 $(\mathrm{wt} \%), W_{i}$ は初期水分 含量 $(\mathrm{wt} \%), R$ は残さ重量比 (=凍結 - 解凍 · 脱水後 の重量/初発試料重量）（wt\%）である.

「給食管理実習 II」の食品廃棄物と食べ残しは，不均 一で水分含量測定が不可能であったため, 残さ重量比 で評価した.

\section{3. 結果}

\section{1 凍結脱水機による凍結・解凍・脱水条件}

凍結脱水機で試料を凍結・解凍させた場合の温度変 化を Fig. 1 に示す. キャべツは丸ごと 1 個（約 $1100 \mathrm{~g}$ ) を 4 等分に切断，ジャガイモは 1 個を皮ごと半分に切 断したものを約 $500 \mathrm{~g}$ ，それぞれ凍結脱水機に投入して 試料の中心部の温度を測定した。 さらに凍結脱水機内 温度と室温も測定した。

キャベッ $(1100 \mathrm{~g})$ は凍結開始までに約 3 時間かかり， 最大水結晶生成温度帯を $7 \sim 8$ 時間で通過して 17 時間 
前後で凍結脱水機の温度まで低下した。解凍は電源を 切ってから約 10 時間で $0{ }^{\circ} \mathrm{C}$ を通過した。ジャガイモ $(500$ g）はやや速く最大水結晶生成温度帯を通過して 15 時 間前後で凍結脱水機の温度まで低下した。解凍も電源 を切ってから 10 時間以内に $0{ }^{\circ} \mathrm{C}$ を通過した。 また，凍 結脱水機の冷却能力は $-20^{\circ} \mathrm{C}$ が限界であった。

Fig. 2 に凍結脱水機の脱水時間による試料の残さ重量 変化を示す. 試料は凍結脱水機で凍結 · 解凍後, 所定 時間脱水してから重量を測定した。キャベッは半個平 均 $780 \mathrm{~g}$ ，ジャガイモは皮ごと半分に切断したものを平 均 $560 \mathrm{~g}$ ，コンニャクは 1 枚を半分に切断したものを平 均 $500 \mathrm{~g}$ 使用した.

いずれの試料も脱水 $10 \sim 20$ 分までは残さ重量が急 激に減少するが，その後はあまり変化しなかった。キャ ベッとジャガイモで残さ重量がやや増加する場合があ るのは，測定ごとに試料が変わり設置位置の影響など もあると考えられた。最も残さ重量比が減少した点を

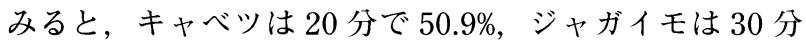
で 43.5\%, コンニャクは 30 分で $20.6 \%$ であった. 前報 [2] で約 $20 \mathrm{~g}$ の試料を遠心機（ユニバーサル冷却遠心機 5700 ，久保田商事(柈) $2328 \mathrm{xg} ３ 0$ 分間で脱水した残さ 重量比は, キャベッ可食部 $43.7 \%$, キャベッ芯 $38.8 \%$, ジャ
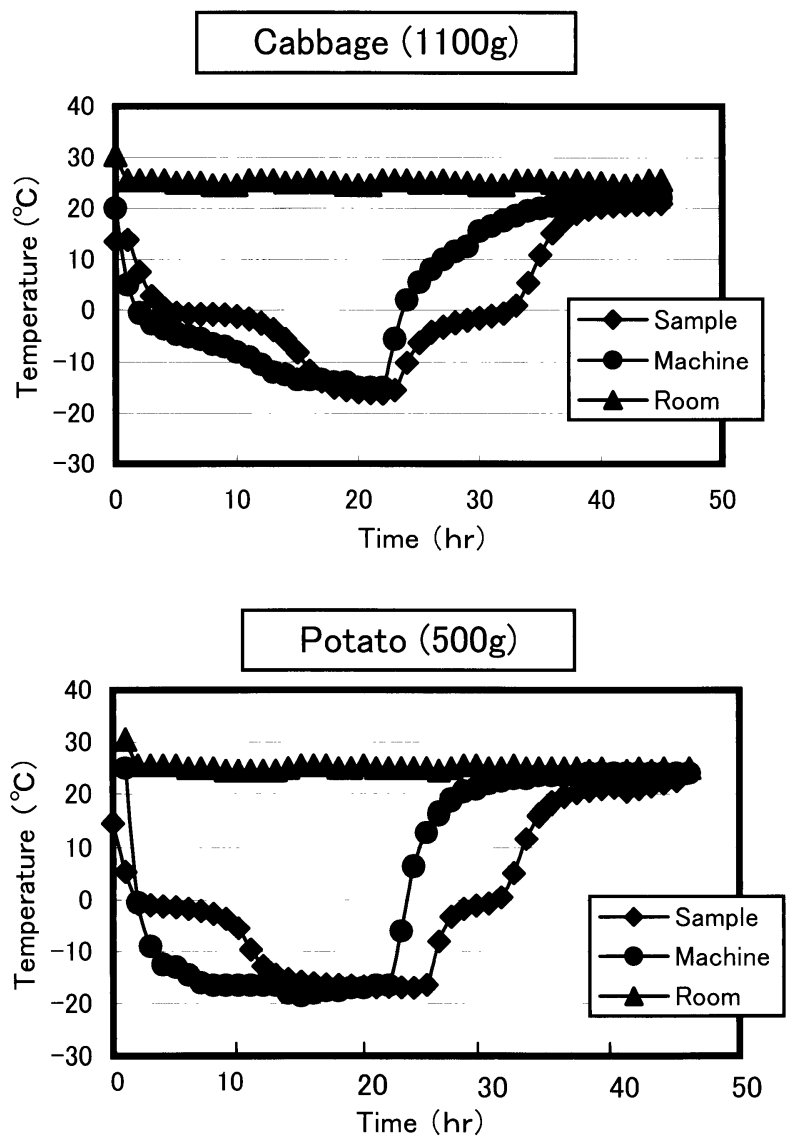

Fig. 1 Temperature change of samples, inside of the freezing-dehydrating machine and the room in the process of freezing-thawing .

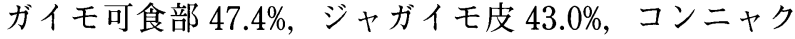
$29.1 \%$ であった。今回用いた凍結脱水機の遠心力は 142 $\mathrm{xg}$ とあまり大きくなかったが，両者を比較するとキャ ベッの脱水率は少し落ちるが他はほぼ同等に脱水した. 前報に打いて凍結・解凍したダイコンとトウフを用い て脱水率に対する遠心力の影響をみた結果，脱水時間 が 30 分の場合は遠心力 $142 \mathrm{xg}$ でも $2328 \mathrm{xg}$ の約 9 割 の脱水効果が認められた。したがって凍結・解凍後の 遠心脱水ではある程度の遠心力で脱水効果が見込める と考えられる. 以上の結果から，凍結脱水機の脱水時 間は 30 分間とした。

\section{2 凍結脱水機による食品試料の脱水効果}

前報では植物性食品およびゲル状食品にとくに脱水 効果がみら机たので，水分含量 $90 \%$ 以上の野菜 11 種, $90 \%$ 以下の野菜 5 種, 果物 6 種, ゲル状食品 3 種につ いて凍結脱水機による凍結・解凍 ・脱水処理を行った. 結果を Table 1 に示す。食品試料は可食部と非可食部を 分けずに 1 回に $500 〜 750 \mathrm{~g}$ を使用した.

Table 1 をみると，水分含量 $90 \%$ 以上の野菜は脱水後 の平均水分含量 $81.62 \%$ ，平均残さ重量比 $37.70 \%$ とかな り脱水されていた，とくに水分が多く組織が軟らかい キュウリ，コマッナ，トマト，ダイコン，ナスなどの 脱水率は高かった。

水分含量 $90 \%$ 以下の野菜の脱水後の平均水分含量は, 63.76\% とかなり低かった。平均残さ重量比は $58.90 \%$ で あったが，ゴボウやサッマイモと比較すると組織の軟 らかいシメジやジャガイモの脱水率は高かった.

果物は糖分が多いために水分含量は野菜よりも低い が，脱水後の平均水分含量は $72.04 \%$ と低かった．平均 残さ重量比は $53.46 \%$ であったが，皮や芯をつけたまま 脱水したために特に皮が脱水されにくいパイナップル，

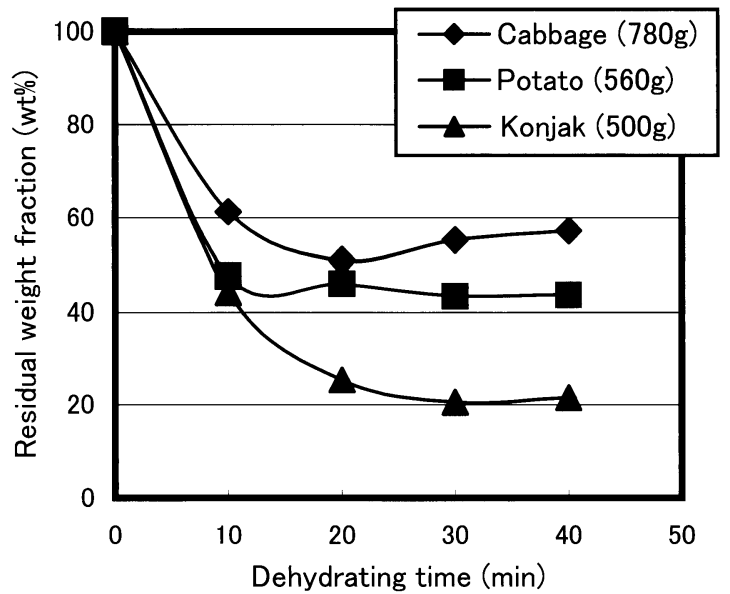

Fig. 2 Effect of dehydrating time on the residual weight fraction of food samples using the freezing-dehydrating machine. Centrifugal force: $142 \mathrm{xg}$ 
Table 1 Freezing-thawing dehydration of food samples by the freezing-dehydrating machine.

\begin{tabular}{|c|c|c|c|c|}
\hline & $\begin{array}{l}\text { Food samples } \\
(500 \mathrm{~g} \sim 750 \mathrm{~g})\end{array}$ & $\begin{array}{c}\text { Initial water content } \\
\text { (wt } \%)\end{array}$ & $\begin{array}{l}\text { Final water content } \\
(\mathrm{wt} \%)^{*}\end{array}$ & $\begin{array}{l}\text { Residual weight fraction } \\
\text { (wt\%) }\end{array}$ \\
\hline Vegetables & Cucumber & 95.45 & 80.92 & 23.85 \\
\hline \multirow[t]{11}{*}{ (water content $>90 \%$ ) } & Chinese cabbage & 95.35 & 77.81 & 20.96 \\
\hline & Tomato & 94.88 & 64.17 & 14.29 \\
\hline & Japanese radish & 94.74 & 82.53 & 30.11 \\
\hline & Cabbage & 94.68 & 90.35 & 55.15 \\
\hline & Eggplant & 94.60 & 77.05 & 23.53 \\
\hline & Sweet pepper & 94.19 & 86.10 & 41.80 \\
\hline & Asparagus & 93.49 & 85.96 & 46.36 \\
\hline & Shiitake mushroom & 93.11 & 86.40 & 50.68 \\
\hline & Carrot & 91.61 & 81.60 & 45.61 \\
\hline & Broccoli & 90.62 & 84.96 & 62.38 \\
\hline & Average & 93.88 & 81.62 & 37.70 \\
\hline Vegetables & Shimeji mushroom & 87.64 & 64.98 & 35.29 \\
\hline \multirow{5}{*}{ (water content $<90 \%$ ) } & Taro & 86.06 & 77.10 & 60.87 \\
\hline & Burdock & 85.05 & 81.71 & 81.73 \\
\hline & Potato & 76.21 & 45.34 & 43.52 \\
\hline & Sweet potato & 63.22 & 49.67 & 73.08 \\
\hline & Average & 79.64 & 63.76 & 58.90 \\
\hline \multirow[t]{7}{*}{ Fruits } & Pineapple & 95.92 & 92.42 & 53.86 \\
\hline & Pear & 88.08 & 64.87 & 33.93 \\
\hline & Apple & 85.89 & 59.79 & 35.09 \\
\hline & Orange & 84.04 & 82.35 & 90.40 \\
\hline & Persimmon & 82.97 & 70.77 & 58.27 \\
\hline & Grape & 81.32 & 62.02 & 49.18 \\
\hline & Average & 86.37 & 72.04 & 53.46 \\
\hline \multirow[t]{5}{*}{ Gel materials } & Konjak gel & 97.04 & 85.62 & 20.59 \\
\hline & Soybean curd & 85.43 & 57.00 & 33.88 \\
\hline & Kamaboko & 77.93 & 72.76 & 81.03 \\
\hline & Average & 86.8 & 71.79 & 45.17 \\
\hline & Average (all) & 88.38 & 74.57 & 46.62 \\
\hline
\end{tabular}

*) calculated water content by eq.(1)

オレンジ，カキなどの脱水にはその影響があったと考 えられる。

ゲル状食品はコンニャクとカマボコの初期水分含量 に $20 \%$ の差があったが, 脱水後の水分含量は $85.62 \%$ (コ ンニャク）と $72.76 \%$ （カマボコ）と差は縮み，残さ重 量比には 20.59\%（コンニャク）と $81.03 \%$ （カマボコ） の差が生じた。 またトウフは凍結変性により物性が変 化して脱水率が上がるので，脱水後の水分含量は $57.00 \%$ ，残さ重量比は $33.88 \%$ とかなり脱水された。

以上の 25 食品の総平均をみると，水分含量は $88.38 \%$ から $74.57 \%$ と $10 \%$ 以上の減少効果が得られ，残さ重量 比は $46.62 \%$ と半減した。

Fig. 3 に凍結脱水機で脱水した食品の例として, コマ ツナ，トマト，ナス，リンゴ，ダイコン，サトイモの 写真を示す．いずれも残さ重量比，水分含量はかなり 低下しており半乾燥状態であった。

3.3 「給食管理実習 II」（130 食）の食品廃棄物および 食べ残しに対する凍結脱水機の脱水効果

凍結脱水機の実用試験として，J女子大管理栄養士専 攻 4 年授業「給食管理実習 II」（130 食）における実習 中の食品廃棄物（調理くず）と供食後の食べ残しを回
収して，凍結脱水機による脱水効果を測定した。料理 様式や調理法によって食品廃棄物や食べ残しの種類と 量が異なるので，Fig. 4 に示すようにそれらを組み合わ せた 3 種類の献立を選択した. $\mathrm{A}$ は洋風で主菜は鮭と 野菜のホイル焼きと温野菜のブロッコリ添え，B は和 風で主菜はたらの揚げ者, 副菜はニンジンと高野豆腐 の炒め物，Cも和風で五目鵎飯と主菜はあんかけ豆腐 であった。

Fig. 5 にそれぞれの献立における食品廃棄物と食べ残 しの回収重量と, 凍結脱水機による処理後の重量, お よび処理後の残さ重量比を示す. 回収重量は献立によっ て異なり, 献立 $\mathrm{A}$ は食品廃棄物も食べ残しも多く, 合 わせて $13 \mathrm{~kg}$ を超える量であった. 献立 B は回収重量 は少なかったが，食べ残しのご飯（麦入り）の割合が 多く, 脱水後の残さ重量比が高かった. しかし B の食 べ残しを除くと, 凍結脱水機処理後の残さ重量比平均 は $53 \%$ と高い脱水効果を示した.

Table 2 に各献立の食品廃棄物を多い順に示す。これ をみるとほとんどが野菜の調理くずで，項目に上がっ た動物系の廃棄は献立 B のかつ打節のだしがらのみで あった。このように給食提供では調理時間や調理師の 人数の関係で肉や魚は切り身のすぐ使える状態で購入 

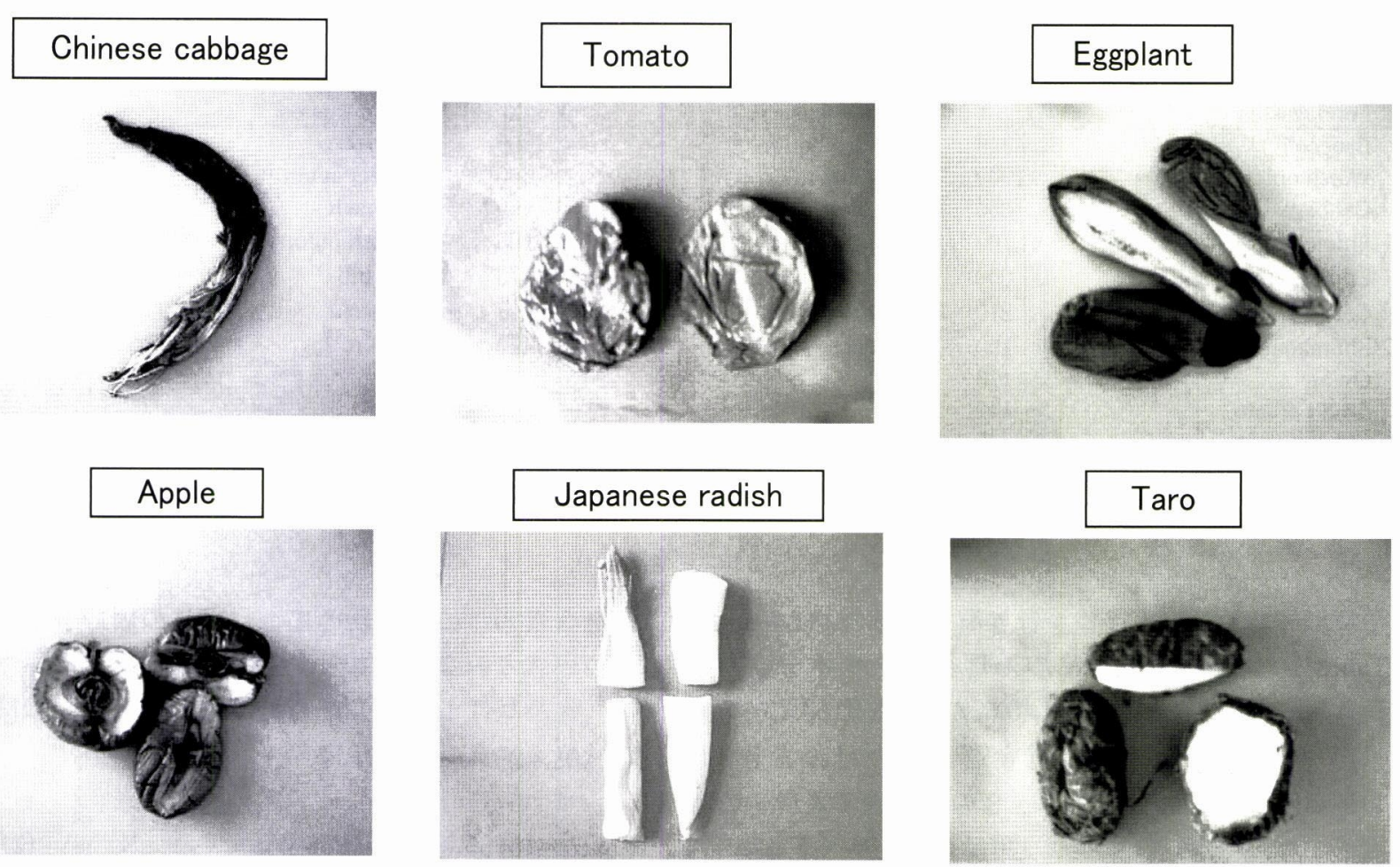

Fig. 3 Food samples after freezing-thawing dehydration by the freezing-dehydrating machine.

するために，食品廃棄物は野菜，果物の調理くずが中 心になる。したがって凍結脱水機による脱水効果が高 くなったと考えられる.

\section{Menu A}

Rice with Sweet Potatoes Julienned Vegetables Soup Salmon and Vegetables Broiled in Foil Boiled Broccoli Tea Jelly

\section{Menu B}

Rice with Barley

Miso Soup with Sweet Potatoes

Fried and Stewed Cod

Sauteed Carrot and Koya-tofu

Grape Jelly

\section{Menu C}

\section{Seasoned Rice}

Consomme Soup with Turnip

Tofu with Sweet Sauce

Spinach in Sesame-seeds Dressing

Candied Sweet Potatoes

Fig. 4 Menus of "Practice of Feeding Management II" which was a practical exercise to make 130 meals for the adult in good health in J women's university.

\section{4. 考察}

今回試作した凍結脱水機は, 一槽式遠心脱水機付洗 濯機に $-40^{\circ} \mathrm{C}$ の冷凍機モータを連結させて, 脱水機の中

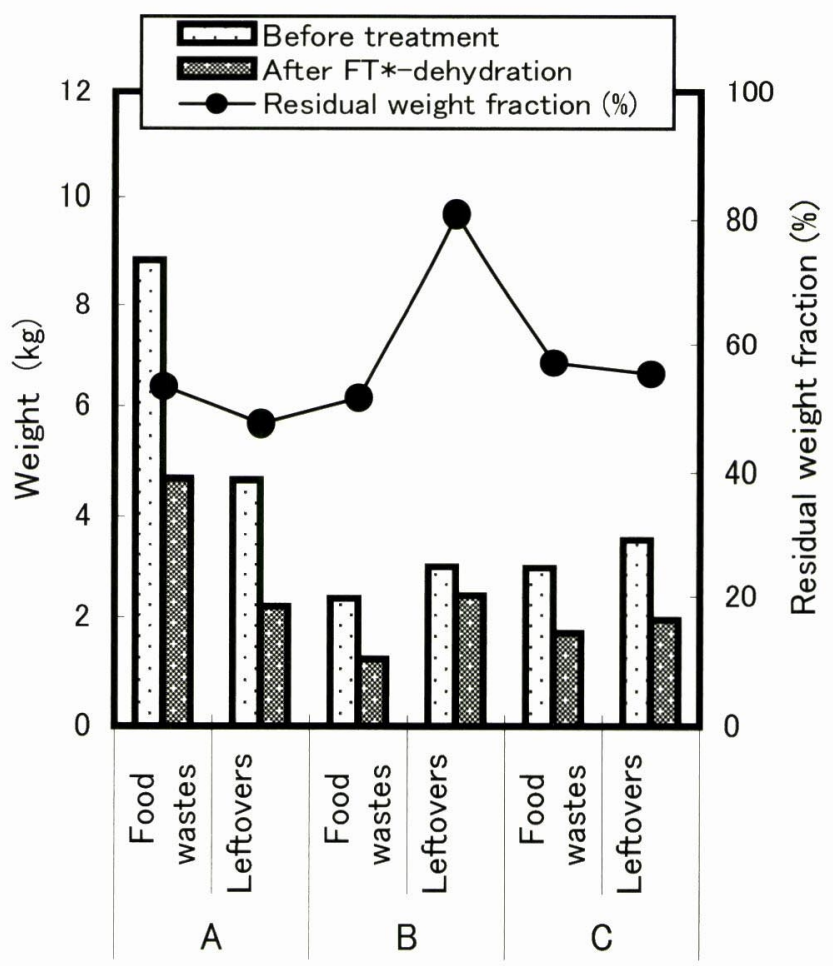

Fig. 5 Food wastes and leftovers of three menus of "Practice of Feeding Management II (130 meals)” in J women's university. *) freezing-thawing 
Table 2 Food wastes which were collected from "Practice of Feeding Management II"

\begin{tabular}{|c|c|c|c|c|c|}
\hline \multicolumn{2}{|c|}{ Menu A } & \multicolumn{2}{|c|}{ Menu B } & \multicolumn{2}{|c|}{ Menu C } \\
\hline Food wastes & Weight (g) & Food wastes & Weight (g) & Food wastes & Weight (g) \\
\hline Broccoli & 4325 & Dried bonito & 1050 & Carrot & 950 \\
\hline Welsh onion & 1200 & Welsh onion & 660 & Sweet potato & 924 \\
\hline Cabbage & 850 & Carrot & 460 & Spinach & 510 \\
\hline Shimeji mushroom & 700 & Ginger & 105 & Welsh onion & 350 \\
\hline Enoki mushroom & 600 & French bean & 75 & Turnip & 130 \\
\hline Carrot & 210 & Sweet potato & 15 & Others & 116 \\
\hline Shiitake mushroom & 190 & Japanese radish & 10 & & \\
\hline Onion & 175 & & & & \\
\hline Sweet potato & 140 & & & & \\
\hline Garden peas & 25 & & & & \\
\hline Others & 453 & & & & \\
\hline Total & 8868 & & 2375 & & 2980 \\
\hline
\end{tabular}

で凍結・解凍・脱水操作を行う簡易なものであったが， Table 1 に示した 25 食品の処理後の平均水分含量は $74.57 \%$, 平均残さ重量比は $46.62 \%$ （重量比 $53.38 \%$ の減 量)，またFig. 5 に示した給食管理実習（130 食分）に おける食品廃棄物回収では，Bの食べ残しを除いた調 理くずと食べ残しの平均残さ重量比が 53\%（重量比 $47 \%$ の減量）と，高い脱水効果が得られた，前報 [2]におい て家庭系食品廃葉物を凍結・解凍・脱水操作によって 処理した場合の減量を $36.7 \%$ と試算したが, 今回の測 定ではそれを大きく上回る減量効果が得られた.

この理由の 1 つは, 今回用いた試料の性質が考えら れる. Table 1 で凍結・解凍・脱水効果を測定した食品 試料は, 前報の結果脱水効率が高かった野菜，果物， ゲル状食品であった。また給食管理実習において は，一般に給食提供では作業効率から肉や魚は献立に 合わせた切り身の状態で購入するという事情がある. したがって給食管理では食品廃棄物は野菜や果物の調 理くずが中心になった。複素インピーダンス測定によ れば植物細胞の膜構造は凍結に対して極めて脆弱であ ることが示されている [6-8]. したがって凍結・解凍後 の植物性食品では今回の凍結脱水機のように $142 \mathrm{xg}$ 程 度の遠心力でも高い脱水効果が得られたと考えられる. また，今回の給食管理実習食べ残しの回収において， ご飯以外は汁気を含んだものが多いことに気付かされ た.このような残飯の汁気も凍結・解凍すると効率よ く脱水できた. 以上のような理由から凍結脱水機によっ て高い脱水効果が得られたと考えられる.

実際の給食提供における食品廃棄物と食べ残しの処 理において平均残さ重量比 $53 \%$ (重量比 $47 \%$ の減量) が得られたことは大きな成果である，家庭においても 肉や魚は切り身の状態で購入することが多くなったの で，食品廃棄物の 40 ～60\% は野菜や果物の調理くずや 食べ残しである [9]. したがって家庭系食品廃棄物に打 いても同様の効果が期待できると考えられる.

本方式を用いることによる廃棄物処理必要エネルギ 変化について考察する. Table 1 における処理前の平均
水分含量 $88 \%$ の廃棄物の場合，残りの固形分 $12 \%$ をグ ルコースとみなすこととする.グルコースの標準燃焼 エンタルピは $15565 \mathrm{~J} / \mathrm{g}$ [10] であるので, この廃棄物 の燃焼エンタルピ $\Delta H_{C}$ は,

$$
\Delta H_{C}=15565 \times 0.12=1868 \mathrm{~J} / \mathrm{g}
$$

これに対して水の蒸発エンタルピ $(2257 \mathrm{~J} / \mathrm{g})$ より, この廃棄物の水分蒸発に必要なエンタルピは,

$\Delta H_{V}=2257 \times 0.88=1986 \mathrm{~J} / \mathrm{g}$

したがって，この廃棄物を燃焼して得られるエネルギ $\Delta H_{T}$ は,

$$
\Delta H_{T}=1868-1986=-118 \mathrm{~J} / \mathrm{g}
$$

すなわち，この廃棄物処理には $118 \mathrm{~J} / \mathrm{g}$ のエネルギ投 入が必要であることがわかる.

これに対して，同様な計算を凍結・解凍・脱水後の 水分含量 $75 \%$ の試料について行うと, 燃焼エンタルピ $\Delta H_{C}{ }^{\prime}$ および水分蒸発エンタルピ $\Delta H_{V}{ }^{\prime}$ は，それぞれ

$$
\begin{aligned}
& \Delta H_{C^{\prime}}=15565 \times 0.25=3891 \mathrm{~J} / \mathrm{g} \\
& \Delta H_{V^{\prime}}=2257 \times 0.75=1693 \mathrm{~J} / \mathrm{g}
\end{aligned}
$$

となる.さらに，凍結に要した全エンタルピ $\Delta H_{F}$ は， 脱水した $53 \%$ の水（残さ重量比 $47 \%$ ）の凍結も含めて 考慮すると，水の凍結潜熱 $334 \mathrm{~J} / \mathrm{g}$ を用いて,

$$
\Delta H_{F}=334 \times(0.75+53 / 47)=628 \mathrm{~J} / \mathrm{g}
$$

したがって，処理後の廃棄物を燃焼して得られるエ ネルギから凍結に要したエンタルピを差し引いた正味 エネルギ $\Delta H_{T}{ }^{\prime}$ は, 
$\Delta H_{T^{\prime}}=\Delta H_{C^{\prime}}-\Delta H_{V^{\prime}}-\Delta H_{F}=1570 \mathrm{~J} / \mathrm{g}$

となる，このことは，凍結・解凍・脱水法を施すこ とによって，凍結に必要なエネルギを差し引いても， この廃棄物処理に打いては $1570 \mathrm{~J} / \mathrm{g}$ の余剩エネルギが 得られることを意味する。

今回得られた結果は，「食品リサイクル法」において 定められた食品事業者に対する $20 \%$ の排出減を大きく 上回っている. 本方法は乾燥法と比較すると, はるか に省エネルギ的であり，ガスなどの発生もなく安全で ある。ささに凍結することによって，生ゴミから発生 するに打いや腐敗も防ぐことができる．今回示したよ うに簡易な操作によって高い脱水率が見込め，水分含 量を $70 \%$ 台に減少できることから，生ゴミ原点处理法 として最適であり，さらにコンポスト化 [11] などの食 品廃棄物再生利用の前処理として, また高い減量率が 得られることから廃棄物輸送においても有効であると 考えられる. 本方法によって脱水された水は排水系に おいて処理されることになるが，その量は排水として は極めて量が少ないため排水系に与える負荷は小さい.

\section{謝辞}

本研究を実施するにあたり，凍結脱水機を製作して 下さいました三洋電機株式会社研究開発本部エコエネ システム研究所上村一朗, 田中努両氏に深く感謝致し ます。また，「給食管理実習 II」に打ける食品廃棄物回 収にご協力いただきました実践女子大学生活科学部食 生活科学科中川靖枝教授，山本さとみ副手に深く感謝 致します．また実験にご協力頂きました実践女子大学 生活科学部調理学第 3 研究室の須藤木綿子, 中町敦子, 平林佳子，福原智江の諸寋に深く感謝致します.

\section{引 用 文 献}

[1] 牛久保明邦; 廃棄物のゼロエミッションの構築と技術, “フードデザイン 21 ”，荒井綜一，川端晶子，茂木信太 郎，山野井昭雄 編，侏サイエンスフォーラム，2002， pp.661-670.

[2] 四宮陽子，宮脇長人; 凍結・解凍効果を利用した食品廃棄 物の脱水処理，日本食品工学会誌，5，153-162（2004）。

[3] 大西茂彦, 宮脇長人; 農産物の凍結障害と力学物性および 電気的物性，低温生物工学会誌，46，99-102（2000）.

[4] P. Dejmek, O. Miyawaki; Relationship between the electrical and rheological properties of potato tuber tissue after various forms of processing. Biosci. Biotechnol. Biochem., 66, 1218-1223 (2002).

[5] S. Ohnishi, Y. Shimiya, H. Kumagai, O. Miyawaki; Effect of freezing on electrical and rheological properties of food materials. Food Sci. Technol. Res., 10, 453-459 (2004).

[6] M. I. Zhang, D. G. Stout, J. H. M. Willison; Electrical impedance analysis in plant tissues: Symplasmic resistance and membrane capacitance in the Hayden model. J. Exper. Botany, 41, 371-380 (1990).

[7] E. S. Cole; Electrical phase angle of cell membrane. J. Gen. Physiol., 15, 641-649 (1932).

[8] 宮脇長人，四宮陽子; 食品廃棄物の凍結·解凍·脱水処理, 化学工学論文集， 28, 618-620 (2002).

[9] 平成 9 年度京都市環境局資料により環境庁作成.

[10] G. M. Barrow（野田春彦訳）；“物理化学，第 2 版”，東京 化学同人, 1995, pp.377-383.

[11] 藤田賢二 ; “コンポスト化技術一廃棄物有効利用のテクノ ロジー”，技報堂出版，1998，p.65.

\section{引 用 URL}

[i] h t t p ://www.jfea.or.jp/kantyo/nousui/ syokuhinjyunkanshigen/syokuhinjyunkansigen.htm （農林水産省；食品循環資源の再生利用等の促進に関する 法律について)

[ii] http://www.maff.go.jp/sogo_shokuryo/kankyou.htm （農林水産省；食品リサイクル関連，食品廃棄物の現状） [iii] http://park2.wakwak.com/ syokuri/

(食品リサイクル機器連絡協議会ホームページ)

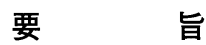

数 $\mathrm{kg}$ の食品廃棄物を省エネルギ，安全な方法である 凍結・解凍・脱水法によって減量処理できる凍結脱水 機を家庭用遠心脱水洗濯機と冷凍機を組み合わせて試 作した。凍結脱水機の冷却能力は $-20^{\circ} \mathrm{C}$, 遠心力は 142 $\mathrm{xg}$ であった．食品試料として 25 種の野菜，果物，ゲ ル状食品を皮や芯をつけて大切りにした状態で $500 \mathrm{~g}$ （回以上処理した結果，処理前の平均水分含量 $88.38 \mathrm{wt} \%$ から, 処理後平均水分含量 $74.57 \mathrm{wt} \%$, 平均残 さ重量比 $46.62 \mathrm{wt} \%$ を得た。 また，給食 130 食を提供す る J 女子大学授業「給食管理実習 II」の調理中食品廃 棄物と食べ残しを 3 日分回収して処理したところ，ご 飯の食べ残しが多かった 1 回分の食べ残しを除いた平 均残さ重量比は，53\% と高い脱水効果が得られた。本 方法は凍結により食品廃棄物特有のに扔いや腐敗の対 策にもなり，高い脱水効果が得られることから，リサ イクルの前処理，輸送，焼却のいずれに対しても有効 であることが期待される。 